\title{
Desain Blade Turbin Pembangkit Listrik Tenaga Arus Laut di Banyuwangi Berbasis CFD
}

\author{
Ricardo M. Lopulalan, Sardono Sarwito, Eddy S. Koenhardono \\ Jurusan Teknik Sistem Perkapalan, Fakultas Teknologi Kelautan, Institut Teknologi Sepuluh \\ Nopember (ITS) \\ Jl. Arief Rahman Hakim, Surabaya 60111 Indonesia \\ e-mail:Sarsan@its.ac.id
}

\begin{abstract}
Abstrak- Turbin arus laut merupakan alat yang dapat menghasilkan energi listrik yang cukup besar. Akan tetapi turbin arus laut yang tersedia di pasaran sejauh ini disesuaikan dengan kondisi asal negara pembuatnya, dimana kecepatan karakteristik arus laut fluktuasi pasang surutnya sangat berbeda dengan karakteristik arus laut dan pasang surut di Indonesia. Oleh karena itu, guna pemanfaatan energi arus laut di Indonesia yang lebih maksimal perlu dilakukan pengembangan perancangan prototipe turbin pembangkit yang cocok dengan karakteristik arus di Indonesia. Pada makalah ini menggunakan metode CFD dengan menggunakan software perangkat lunak. Validasi dari hasil software dibandingkan dengan menggunakan persamaan yang telah diaplikasikan. Kajian dilakukan untuk pembangkit listrik tenaga arus laut di Banyuwangi. Kajian meliputi tipe turbin, besarnya Coefisien lift, besarnya gaya hidrodinamik, torsi dan besarnya daya yang dihasilkan. Hasil yang diperoleh nantinya desain turbin yang menghasilkan daya terbesar yang diaplikasikan di Banyuwangi. Daya listrik terbesar dihasilkan oleh tipe blade dengan jumlah daun 4 dan ketinggian $3 \mathrm{~m}$ sebesar 349 Watt.
\end{abstract}

Kata Kunci- Ocean current, CFD, Gaya Hidrodinamik, Pembangkit Listrik, Turbin Gorlov

\section{PENDAHULUAN}

$\mathrm{E}$ NERGI terbarukan (renewable energy) merupakan sumber energi alternatif yang menjanjikan untuk dimanfaatkan sebagai sumber energi listrik masa depan. Posisi geografis Indonesia di antara dua samudra dan benua serta di daerah khatulistiwa, sehingga mempunyai potensi sumber terbarukan yang berlimpah. Salah satu pemanfaatan potensi sumber energi terbarukan Indonesia adalah pemanfaatan arus laut (ocean current) sebagai sumber energi penghasil listrik. Energi mekanis dari arus laut dapat digunakan untuk menggerakkan turbin. Salah satu jenis turbin yang dapat dipergunakan untuk menangkap arus laut adalah turbin gorlov yag merupakan jenis turbin vertical.

Pemanfaatan energi dari arus laut dapat menjadi salah satu solusi terhadap permasalahan nasional yang terjadi saat ini berkaitan dengan belum tercapainya target proyeksi Bauran Energi Nasional sebagaimana Peraturan Presiden No. 5 tahun 2006 dan Blueprint Pengelolaan Energi Nasional (PEN) 2006
- 2025. Saat ini, penggunaan energi yang berasal dari sumber energi fossil masih sangat tinggi, padahal potensi sumbersumber energi baru dan terbarukan (EBT), seperti energi laut dan panas bumi (geothermal), sudah diketahui. UndangUndang No. 30/2007 tentang Energi menyatakan bahwa EBT harus mencapai 25,9\% dalam Bauran Energi Nasional pada tahun 2025 pada Gambar 1. Target tersebut jauh lebih tinggi dibandingkan dalam Peraturan Presiden maupun Blueprint Pengelolaan Energi Nasional sehingga upaya penemuan dan pemanfaatan EBT harus ditingkatkan. Keterbatasan sumber daya energi akan menjadi kendala yang dapat menghambat laju pertumbuhan ekonomi di kemudian hari.

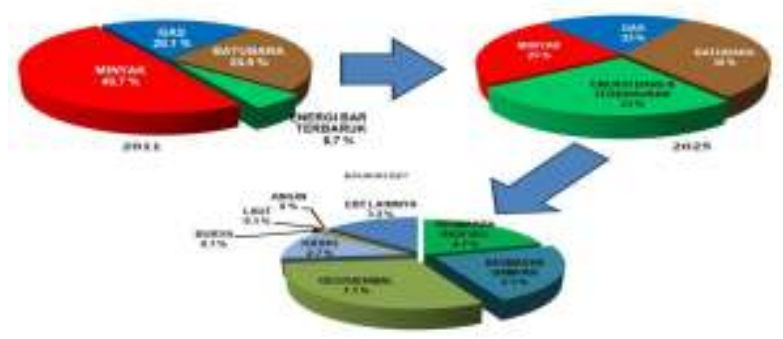

Gambar .1. Status Bauran Energi Nasional tahun 2011 dan harapan tahun 2025 menurut Rencana Induk Kebijakan Energi Nasional 2014

Peningkatan kebutuhan energi sejalan dengan pertumbuhan penduduk yang pesat serta adanya keterbatasan sumber daya energi fosil yang tersedia mengakibatkan perlunya dikembangkan teknologi pemanfaatan sumber energi terbarukan yang salah satunya adalah energi arus laut. Untuk keperluan tersebut maka diperlukan instalasi turbin arus laut sebagai piranti untuk mengkonversi energi arus menjadi listrik. Akan tetapi pemanfaatan energi arus laut sebagai pembangkit listrik atau Pembangkit Listrik Tenaga Arus Laut (PLTAL) di Indonesia menghadapi beberapa kendala, terutama disebabkan oleh kapasitas nasional terhadap penguasaan teknologi energi laut masih terbatas. 


\section{A. Energi}

Dalam Hukum Termodinamika pertama, energi itu bersifat kekal. Energi tidak dapat diciptakan dan tidak dapat dimusnahkan, tetapi dapat dikonversi atau diubah dari bentuk energi yang satu ke bentuk energi yang lain.

Energi yang dapat diperbaharui adalah energi yang berasal dari proses alam yang berkelanjutan. Istilah dari energi tersebuat adalah energi berkelanjutan. Artinya natar lain energi ini dapat diperbaharui selama-lamanya, selama masih ada sumber energi yang dapat digunakan untuk memperbaharuinya. Energi yang tidak dapat diperbaharui adalah energi yang berasal dari proses alam yang tidak berkelanjutan. Selama masih ada sumber energi ini, maka energi tersebut dapat digunakan akan tetapi ketika sudah habis maka tidak bisa diperbaharui lagi.

Salah satu sumber energi terbarukan adalah Energi Laut. Energi ini selanjutnya dibagi menjadi 4 kategori antara lain : Energi gelombang, Energi Pasang Surut, Energi Arus Laut, dan energy panas laut. Energi laut merupakan energi yang dihasilkan dari samudera dan laut, dan tentu saja merupakan sumber energi hijau terbarukan karena mengkonversi gaya mekanik, gaya potensial dan perbedaaan temperature air laut

Energi Arus laut adalah gerakan masa air secara teratur dari suatu tempat ketempat lain. Sebagaian besar arus laut bergerak dengan arah horinzontal dan hanya sebagian kecil bergerak dengan arah vertical. Gerakan masa air laut secara vertical disebut upwelling [2]. Berdasarkan device penangkap arus laut dibagi menjadi 5 jenis yaitu turbin sumbu horizontal, turbin sumbu vertical, ocilating hydrofoil, achimedes screw, layang-layang pasang surut.

Salah satu turbin arus vertical adalah Turbin Gorlov Helikal adalah jenis turbin yang baru dikembangkan pada tahun 1995, mengubah energi kinetik yang dihasilkan oleh arus aliran menjadi energi mekanis/gerak putar, di temukan oleh Profesor Gorlov dari Northeastern University, jenis turbin ini diperuntukan untuk energi arus sungai (river energy), energi arus laut (marine energy) dan energi arus pasang-surut (tidal energy).

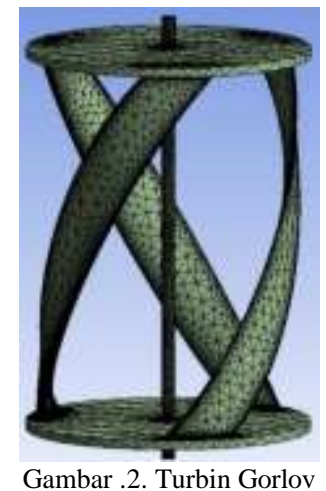

Dalam Pembuatan model turbin arus laut gorlov untuk sudut helix atau sudut pada daun turbin dapat dipengaruhi oleh beberapa factor jumlah daun turbin, ketinggian turbin dan diameter dari turbin. Sudut ini dapat di hitung dengan menggunakan persamaaan sebagai berikut :

$$
\varphi=\arctan \left\{\frac{B \cdot h}{\pi \cdot D}\right\}
$$

(1)

dimana :

$\mathrm{B}=$ Jumlah daun blade;

$\mathrm{h}=$ Ketinggina Turbin $(\mathrm{m})$;

$\mathrm{D}=$ Diameter $(\mathrm{m})$.

Perbandingan efisiensi dan daerah operasi turbin Dapat dilihat pada tabel .1.

\begin{tabular}{llc}
\multicolumn{2}{c}{ Tabel .1. Efisiensi Dan Daerah Operasi Turbin } \\
\hline \hline Jenis Turbin & Efisiensi & Daerah operasi arus \\
\hline Gaman & $15 \%-18 \%$ & $>0,5 \mathrm{~m} / \mathrm{s}$ \\
Tyson & $16 \%$ & $>0,5 \mathrm{~m} / \mathrm{s}$ \\
Savonius & $19 \%$ & $>2 \mathrm{~m} / \mathrm{s}$ \\
Seaflow & $20 \%$ & $>2 \mathrm{~m} / \mathrm{s}$ \\
Darrieus & $23 \%$ & $>2 \mathrm{~m} / \mathrm{s}$ \\
Gorlov & $35 \%$ & $>0,6 \mathrm{~m} / \mathrm{s}$ \\
Verdant & $43 \%$ & $>2 \mathrm{~m} / \mathrm{s}$
\end{tabular}

Menurut penelitian yang dilakukan Gorlov [3] kelebihan dari turbin arus gorlov antara lain :

- Dapat beroperasi di laut air pasang surut dan arus sungai

- Dapat berputar pada kecepatan air 0,6 m/s,

- Berputar tanpa fluktuasi, Berputar pada satu arah saja

Balam pembuatan model menggunakan bentuk airfoil dari NACA. NACA airfoil adalah salah satu bentuk bodi aerodinamika sederhana yang berguna untuk dapat memberikan gaya angkat tertentu terhadap suatu bodi lainnya dan dengan bantuan penyelesaian matematis sangat memungkinkan untuk memprediksi berapa besarnya gaya angkat yang dihasilkan oleh suatu bodi airfoil. Geometri airfoil memiliki pengaruh besar terhadap karakteristik aerodinamika dengan parameter penting berupa $\mathrm{Cl}$ (koefisie lift).

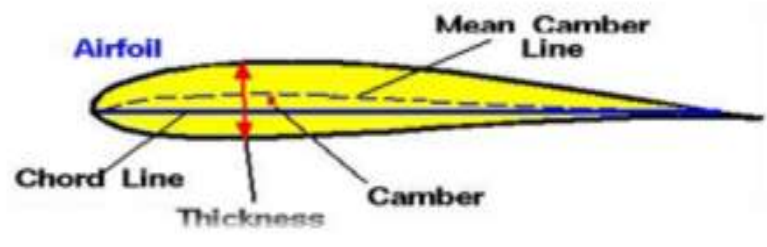

Gambar 3. NACA Airfoil Geometry

Agar proses penggambaran Naca lebih teliti maka harus dihitung terlebih dahulu nilai panjang chord yang diperoleh dengan rumusan berikut :

$$
c=\frac{2 \sigma \pi \mathrm{r}}{B}
$$


Dimana :

$\mathrm{B}=$ Jumlah Blade

$\sigma=$ Solidity $(0,5)$

Setelah penggambaran bentuk airfoil maka dilakukan analisa Gaya hidrodinamik terjadi karena aliran yang masuk ke blade turbin sehingga menghasilkan torsi yang mendorong blade sehingga turbin dapat berputar. Gaya hidrodinamik dipengaruhi oleh beberapa faktor antara lain sifat fluida, kecepatan fluida, dan luas dari dimensi blade turbin. Rumus Umum yang digunakan untuk mencari Gaya hidrodinamik adalah sebagai berikut :

$$
\begin{aligned}
& \mathrm{F}=0.5 \times \rho \times \mathrm{v}^{2} \times \mathrm{c} \times \mathrm{h} \times \mathrm{Cl} \\
& \text { dimana } \\
& \mathrm{F}=\text { Gaya }(\mathrm{N}) ; \\
& \rho=\text { rapat massa air }\left(\mathrm{kg} / \mathrm{m}^{3}\right) ; \\
& \mathrm{v}=\operatorname{kecepatan} \text { arus }(\mathrm{m} / \mathrm{s}) . \\
& \mathrm{c}=\text { Lebar Chord }(\mathrm{m}) ; \\
& \mathrm{d}=\text { tinggi blade }(\mathrm{m}) ; \\
& \mathrm{Cl}=\text { Coefisien Lift }
\end{aligned}
$$

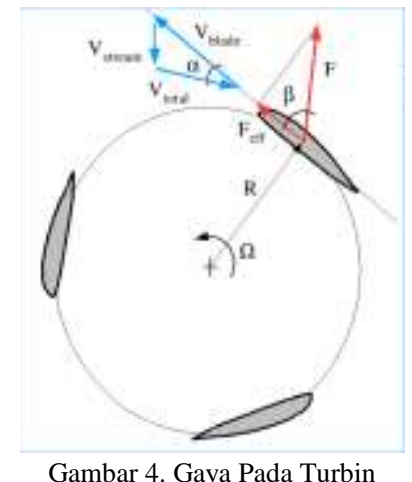

Setelah dilakukan analisa terhadap gaya pada blade maka dapat diketahu torsi yang dihasilkan dengan mengalikan besarnya gaya yang diterima oleh blade dengan jari-jari turbin. Setelah itu perhitungan daya dapat dicari dengan formula sebagai berikut [4]:

(P) $=\mathrm{T} \times \mathrm{RPM}$

(4)

$$
\begin{aligned}
& \mathrm{RPM}=\frac{\mathrm{nx60}}{2 \pi} \\
& \Omega=\omega / \mathrm{R}
\end{aligned}
$$

dimana :

$\mathrm{P}=$ daya $($ Watt);

$\mathrm{T}=$ Torsi Poros Rotor;

$\omega=$ Kecepatan Anguler Turbin; dan

$$
\mathrm{R}=\text { Jari jari turbin. }
$$

\section{METODE PENELITIAN}

Dalam penelitian ini, tahapan pertama adalah melakukan studi literatur dan studi empiris. Studi empiris terkait terkait tahapan proses dalam menentukan turbin yang sesuai dengan karakteristik arus laut. Sumber yang digunakan sebagai acuan dapat berasal dari buku, jurnal, paper dan Internet. Setelah dilakukan studi literatur terkait penentuan turbin langkah selanjutnya mengumpulkan data-data yang diperlukan dalam pemodelan. Kemudian melakukan identifikasi variable untuk mendapatkan variable serta parameter yang akan digunakan dalam melakukan pemodelan. Setelah variabel didapat kemudian melakukan pengerjaan penginputan model blade 3D yang telah dibuat setelah itu langsung dimasukkan ke software komputer. Kemudian melakukan validasi terhadap model yang telah didesain untuk mengetahui kemungkinan terjadi eror pada model yang telah dibuat. Validasi dilakukan tidak hanya pada data yang didapatkan namun evaluasi secara menyelurus terkait metode juga tahapan pelaksanaannya.

Dengan dilakukan analisa terhadap hasil simulasi dari model, maka dapat diambil kesimpulan tentang desain blade yang maksimum yang dapat memberikan daya listrik terbesar dan dapat diterapkan di Banyuwangi. Kesimpulan meliputi semua hasil penelitian, termasuk simulasi, perhitungan, dan lain-lain. Kesimpulan ini akan menjawab poin-poin yang sudah dirumuskan dalam tujuan dan selanjutnya juga memberikan saran-saran berdasarkan hasil penelitian untuk pengembangan penelitian selanjutnya. 


\section{A. Spesifikasi Turbin Gorlov}

Spesifikasi dari turbin Gorlov yang dirancang sebagai berikut :

1. Tipe NACA Series 4 Digit 0018

- Jumlah Blade = 3 Buah

- Tinggi turbin $=1.5$ meter

- Diameter Turbin $\quad=1$ meter

- Panjang Chord Blade $=0.5$ meter

2. Tipe NACA Series 4 Digit 0018

- Jumlah Blade = 4 Buah

- Tinggi turbin $=1.5$ meter

- Diameter Turbin = 1 meter

- Panjang Chord Blade $=0.392$ meter

3. Tipe NACA Series 4 Digit 0018

- Jumlah Blade = 3 Buah

- Tinggi turbin = 2 meter

- Diameter Turbin = 1 meter

- Panjang Chord Blade $=0.5$ meter

4. Tipe NACA Series 4 Digit 0018

- Jumlah Blade = 4 Buah

- Tinggi turbin = 2 meter

- Diameter Turbin $\quad=1$ meter

- Panjang Chord Blade $=0.392$ meter

5. Tipe NACA Series 4 Digit 0018

- Jumlah Blade = 3 Buah

- Tinggi turbin $=3$ meter

- Diameter Turbin $\quad=1$ meter

- Panjang Chord Blade $=0.5$ meter

6. Tipe NACA Series 4 Digit 0018

- Jumlah Blade =4 Buah

- Tinggi turbin $=3$ meter

- Diameter Turbin $\quad=1$ meter

- Panjang Chord Blade $=0.392$ meter

\section{B. Simulasi CFD pada Turbin Gorlov}

Computational Fluid Dynamics (CFD) adalah cabang dari mekanika fluida yang menggunakan metode numerik dan algoritma untuk memecahkan dan menganalisis masalah yang melibatkan dari aliran fluida tersebut. Pada analisis ini komputer digunakan untuk melakukan perhitungan yang diperlukan untuk mensimulasikan interaksi cairan dan gas dengan permukaan yang didefinisikan oleh kondisi batas, dengan kecepatan tinggi superkomputer, agar hasil analisis yang lebih baik dapat dicapai. Code CFD terstruktur atas logaritma numeric, sehingga dapat digunakan untuk menyelesaikan problem pada suatu aliran fluida.

Simulasi CFD pada turbin gorlov digunakan untuk mengetahui besarnya gaya putar pada turbin yang diakibatkan arus laut dengan kecepatan tertentu yang mengenai turbin, sehingga nantinya dari besarnya gaya pada turbin dapat digunakan untuk mendapatkan besarnya torsi yang dihasilkan oleh turbin. Setelah mendapatkan torsi pada turbin maka didapatkan daya listrik yang bias dihasilkan oleh turbin.

Pengerjaan simulasi turbin gorlov memerlukan beberapa tahapan pengerjaan sesuai dengan Table 2 . berikut ini.

\begin{tabular}{cl} 
& Tabel 2. Proses Tahapan Simulasi \\
\hline \hline No & \multicolumn{1}{c}{ Proses Pengerjaan } \\
1 & Pembuatan Geometri Airfoil NACA 0018 \\
2 & Penggambaran 3 Dimensi Turbin Gorov \\
3 & Simulasi Pre-Processor dan Solver \\
4 & Post Processor
\end{tabular}

Permodelan Geometri dari Airfoil turbin di buat dengan menggunakan software komputer. Untuk mencari koordinat dari geometri Airfoil Naca 0018 maka menggunakan persamaan dari standart penggambaran NACA empat digit 0018. Koordinat-koordinat dari geometri Airfoil dimasukkan kedalam software komputer. Geometri Airfoil turbin dengan Naca empat digit 0018 seperti gambar 6.

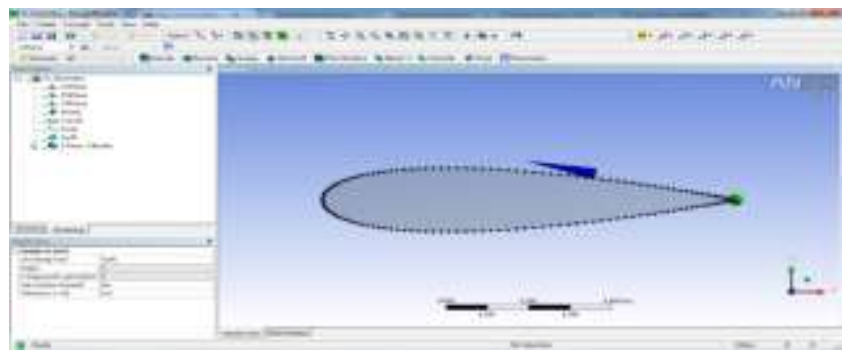

Gambar 5. Pembuatan Naca 0018 Software komputer

Pemodelan 3 dimensi dari turbin gorlov digambar pada software komputer. Setelah permodelan Geometri dari Airfoil turbin, maka langkah selanjutnya penggambaran 3 Dimensi dengan koordinat Naca yang telah didapat.

\section{Simulasi}

Simulasi pada software computer terdapat tahapan-tahapan dalam pengolahan yaitu simulasi :

\section{Pre-Processor}

Tahapan dimana data diinput mulai dari pendefinisian domain serta pendefinisian kondisi batas atau boundary condition. Ditahap ini juga sebuah benda atau ruangan yang akan dianalisis dibagi-bagi dengan jumlah grid tertentu atau sering juga disebut dengan meshing. Meshing digunakan untuk akurasi modeling dengan hasil perhitungan. Nantinya solver akan memperhalus seperti pada bagian ujung-ujung, atau sudut. Untuk ukuran meshing digunakan ukuran yang terkecil supaya nantinya model semakin seragam dan pola separasi pada turbin semakin seragam.

\section{Solver}


Tahap ini dilakukan proses penghitungan data-data input dengan persamaan yang terlibat secara iteratif. Artinya penghitungan dilakukan hingga hasil menuju error terkecil atau hingga mencapai nilai yang konvergen. Penghitungan dilakukan secara menyeluruh terhadap volume kontrol dengan proses integrasi persamaan diskrit. Pada tahapan ini parameter yang digunakan untuk maksimal iterasi sebesar 100 dan timescale Control yaitu Automatic time Scale. Semakin besar nilai iterasi maka hasil yang akan diperoleh saat simulasi semakin akurat.

\section{Post Processor}

Tahap akhir merupakan tahap post processor di mana hasil perhitungan diinterpretasikan ke dalam gambar, grafik bahkan animasi dengan pola warna tertentu. Untuk memvalidasi data digunakan fungtion calculator yang dari data tersebut dapat dianaliasa berapa besarnya gaya yang diterima oleh blade di setiap bagian turbin.

\section{Validasi}

Validasi adalah membandingkan gaya yang di dapatkan dengan menggunakan software computer dengan perhitungan matematis. Untuk membuktikan bahwa hasil simulasi masih memenuhi maka perlu dilakukan validasi data dengan cara menghitung secara teori. Dari validasi tersebut terjadi perbedaan hasil antara perhitungan matematis dengan menggunakan software komputer. Perbedaan tersebut merupakan prosentase error.

\section{HASIL DAN DISKUSI}

\section{A. Analisa Grafik Potensi Arus Laut di Banyuwangi}

Arus laut sangat mempengaruhi kerja kerja turbin. Pemilihan lokasi dilakukan untuk mendapatkan data potensi arus laut yang terbesar. Gambar 7 Grafik potensi arus laut di pantai Grajakan.

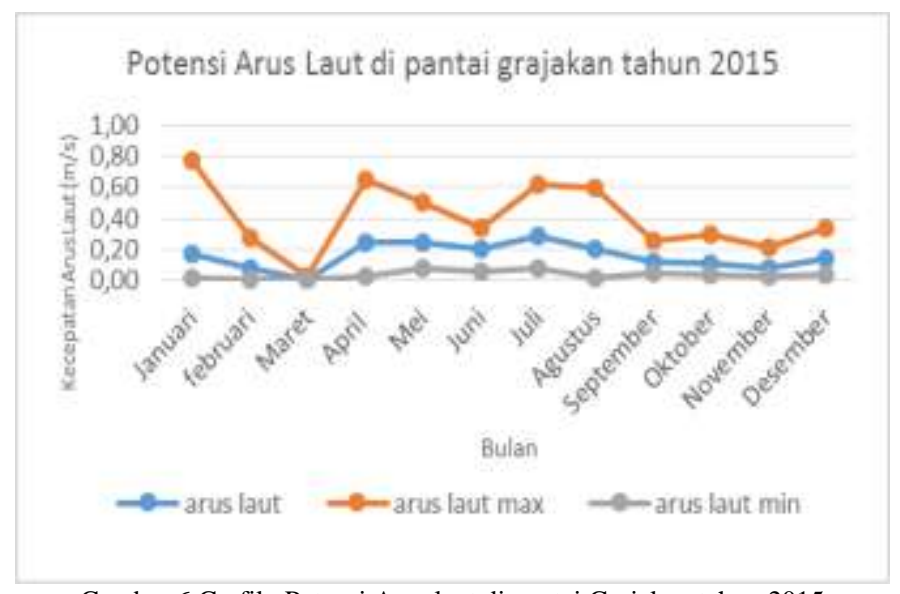

Gambar 6 Grafik Potensi Arus laut di pantai Grajakan tahun 2015

Gambar 7 terlihat bahwa potensi arus laut terbesar terjadi pada bulan Juli dengan rata-rata kecepatan arus laut $0,29 \mathrm{~m} / \mathrm{s}$ dan untuk potensi terendah arus laut terdapat pada bulan maret dengan rata-rata arus $0,01 \mathrm{~m} / \mathrm{s}$.

Potensi arus laut terbesar di pantai muncar pada tahun 2015 terlihat pada gambar 8 terjadi pada bulan juli dengan rata-rata kecepatan arus laut $0,023 \mathrm{~m} / \mathrm{s}$. Potensi arus lautterendah pada tahun 2015 terjadi pada bulan Maret dengan rata-rata arus $0,004 \mathrm{~m} / \mathrm{s}$.

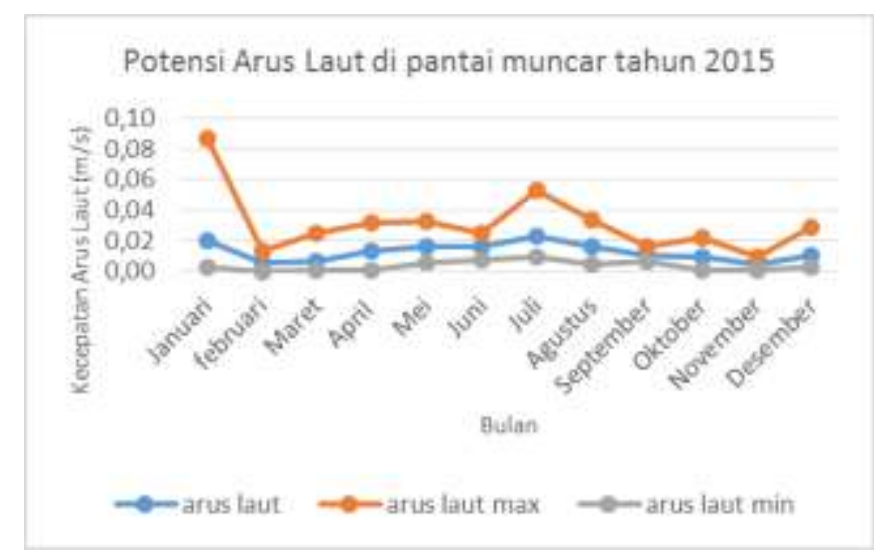

Gambar 8 Grafik. Potensi Arus laut di pantai Muncar tahun 2015

\section{B. Analisa Koefisien Terhadap Sudu Serang}

Naca mempengaruhi dari karakteristik system kerja turbin. Pemilihan dari Naca akan mempengaruhi geometri dari blade yang di didesain. Sehingga nantinya mempengaruhi kinerja sudu dari turbin. Pada kecepatan aliran fluida yang melewati turbin mempunyai koefisien lift yang naik pada kondisi reynold tertentu. semakin besar sudu serang maka nilai dari coefisien lift semakin besar hingga maksimal. Akan tetapi sudu serang yang terlalu besar akan menyebabkan aliran terpisah dari permukaan foil dan mengakibatkan gaya dorong akan berkurang.

\section{Analisa Hasil Simulasi}

Data yang diperoleh dari hasil simulasi digunakan untuk menghitung besarnya torsi dan daya listrik yang dihasilkan oleh turbin yang dirancang. Berikut data gaya yang diperoleh dari proses hasil simulasi berdasarkan variasi kecepatan arus $0.01-0.29 \mathrm{~m} / \mathrm{s}$. 


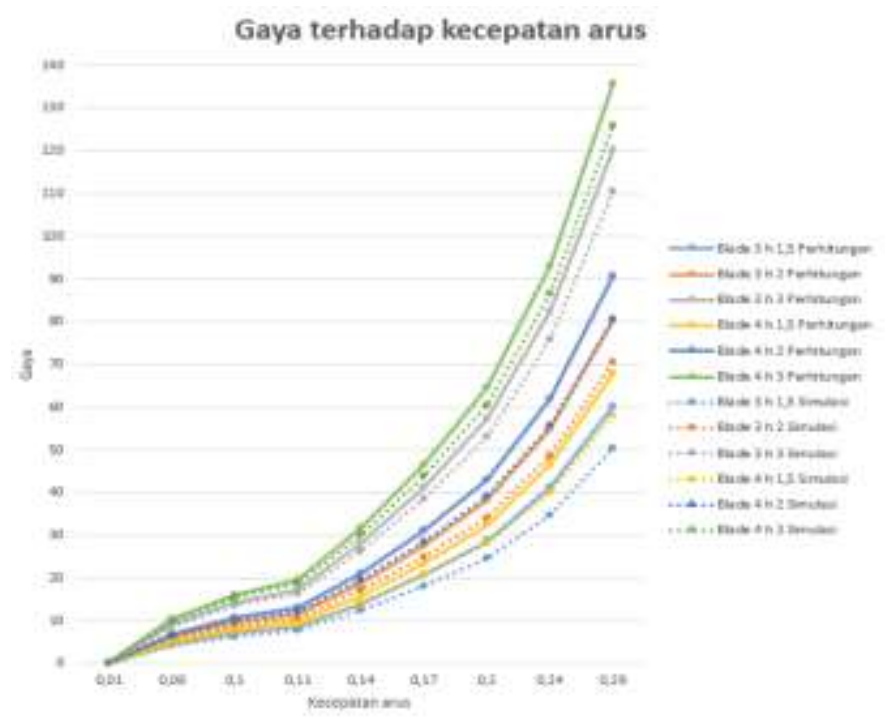

Gambar 9 Grafik Gaya Hidrodinamik yang diperoleh dari simulasi

Gambar 9 Grafik merupakan hasil simulasi komputer yang menghasilkan nilai output berupa gaya yang bekerja pada blade turbin. Pada grafik diatas dapat terlihat perbandingan Gaya Hidrodinamik berbanding lurus terhadap besarnya kecepatan fluida yang masuk ke turbin, Sehingga semakin besar Kecepatan arus maka nilai dari Gaya Hidrodinamik semakin besar hingga maksimal $125.962 \mathrm{~N}$.

\section{Perhitungan Torsi}

Dengan mendapatkan Gaya hidrodinamik maka dapat diperoleh perhitungan torsi sesuai persamaan berikut :

$$
\begin{aligned}
& \mathrm{T}=\mathrm{F} \times \mathrm{r} \\
& \mathrm{T}=120,25 \times 0.5 \\
& \mathrm{~T}=60,12 \mathrm{Nm}
\end{aligned}
$$

Pada gambar 10 terlihat kecepatan arus berbanding lurus terhadap besarnya torsi yang dihasilkan turbin, Sehingga semakin besar Kecepatan arus maka nilai dari Torsi yang dihasilkan semakin besar yang paling besar pada kecepatan arus $0.29 \mathrm{~m} / \mathrm{s}$ yakni $62,981 \mathrm{Nm}$.

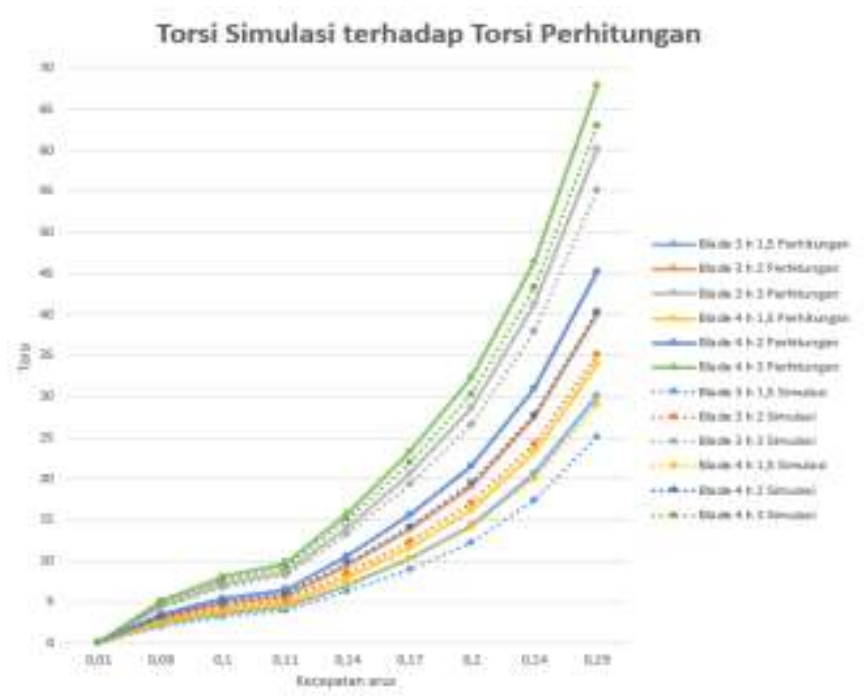

Gambar 10 Grafik Torsi yang diperoleh dari simulasi

\section{E. Perhitungan Daya}

Daya Listrik dihitung dari nilai torsi yang telah diperoleh dengan persamaan sebagai berikut :

$$
\begin{gathered}
(\mathrm{P})=\mathrm{T} \times \mathrm{RPM} \\
(\mathrm{P})=\mathrm{Tx} \frac{\operatorname{nx60}}{2 \pi} \\
(\mathrm{P})=\mathrm{Tx} \frac{\operatorname{wx} 60}{r 2 \pi} \\
(\mathrm{P})=60,12 \times \frac{0.1 \times 60}{0.5 \times 2 \times 3.14}=333 \mathrm{Watt}
\end{gathered}
$$

Pada gambar 11 terlihat perbandingan Kecepatan arus berbanding lurus terhadap besarnya torsi yang dihasilkan turbin, Sehingga semakin besar Kecepatan arus maka nilai dari Torsi yang dihasilkan semakin besar yang paling besar pada kecepatan arus $0.29 \mathrm{~m} / \mathrm{s}$ yakni 349 Watt.

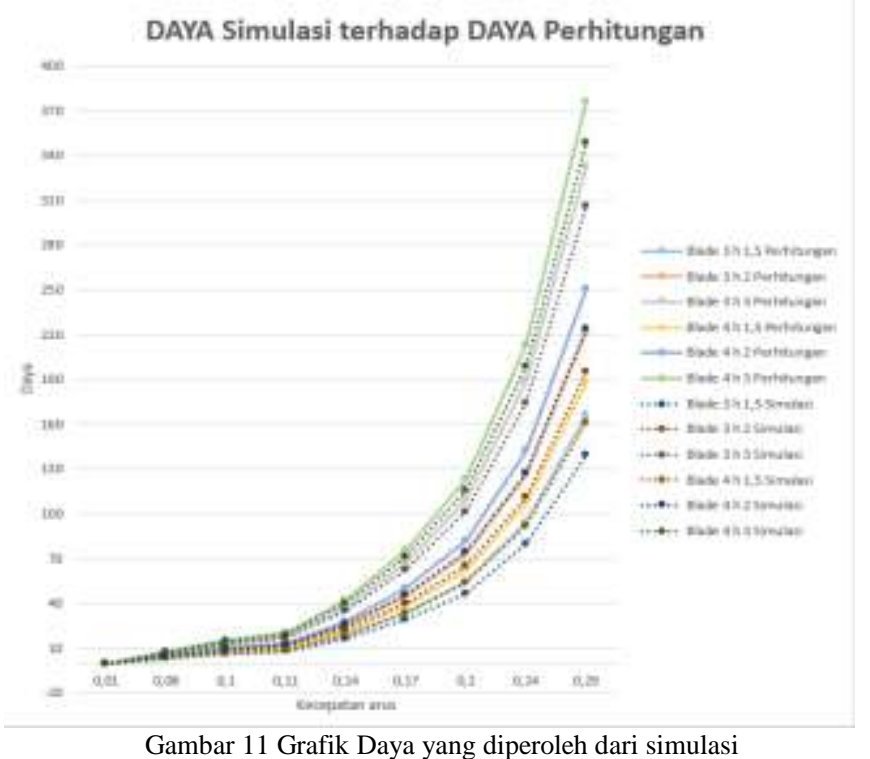




\section{F. Prosentase Error}

Prosentase error yang terjadi sebagai pada penelitian ini seperti yang terlihat pada gambar 12 Grafik Prosentase Error Hasil Simulasi.

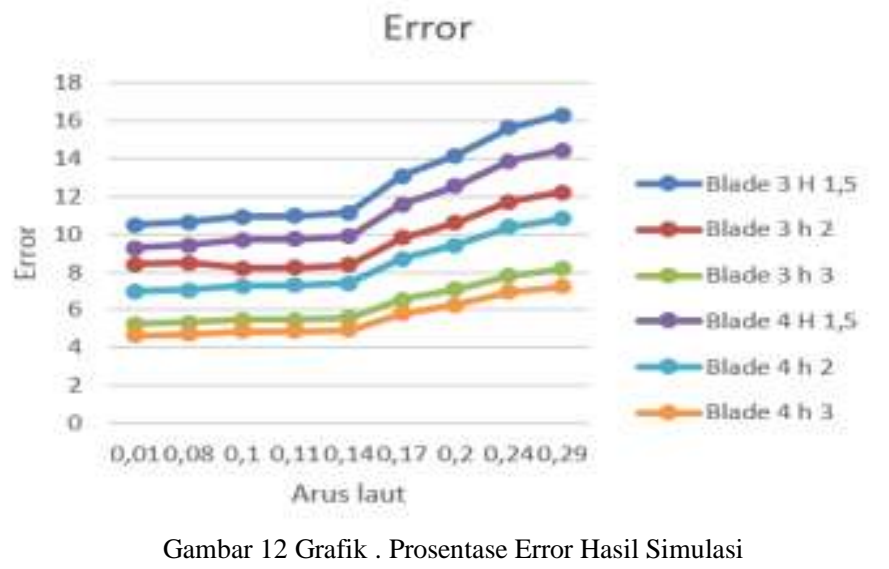

Pada gambar 12 grafik menunjukkan bahwa semakin besar kecepatan arus laut semakin besar juga tingkat prosentase eror. Hal ini dikarenakan simulasi pada software masih ada tingkat kesalahan yang disebabkan oleh nilai meshing yang kurang tinggi.

\section{KESIMPULAN}

Berdasarkan analisis dan pembahasan dapat disimpulkan bahwa Dengan kondisi arus pasang surut yang memiliki kecepatan arus berkisar 0,1 sampai 0,7 laut di banyuwangi maka turbin tipe vetikal gorlov cocok diaplikasikan di banyuwangi. Dengan bertambah ketinggian dari turbin $3 \mathrm{~m}$ akan mengakibatkan torsi dan daya listrik sebesar $62,98 \mathrm{Nm}$ dan 349 watt. Sudut serang $15^{\circ}$ akan memberikan gaya dorong optimal sebesar $125,96 \mathrm{~N}$

\section{DAFTAR PUSTAKA}

[1] Achirudhin .D, 2011. Ocean energy, Universitas darma Persada

[2] Mahammad, hamid. 2005.Jakarta: Ilmu Pengetahuan Sosial Geografi Direktorat Pendidikan Lanjutan Pertama, Direktorat Jenderal Pendidikan Dasar dan Menengah. Departemen Pendidikan Nasional.

[3]Gorlov, 2001. Limits of the Turbine Efficiency for Free Fluid Flow. Institute of Computational Modeling, Krasnoyarsk, Russia.

[4]Hincley, Dr Michael.Design, Fabrication and Testing of a Water Current Energy Device. (n.d.). Memorial University of Newfoundland. 